\title{
Desempenho de escolares na adaptação brasileira da avaliação dos processos de leitura***
}

\author{
School-aged children's performance in the Brazilian adaptation of the \\ reading processes assessment
}

Adriana Marques de Oliveira* Simone Aparecida Capellini**

\begin{abstract}
*Fonoaudióloga. Mestranda do Programa de Pós-Graduação em Educação da Faculdade de Filosofia e Ciências da Universidade Estadual Paulista (FFC/Unesp). Bolsista do Conselho Nacional de Desenvolvimento Científico e Tecnológico - CNPq. Endereço para correspondência: R. Mato Grosso, 285 - Marília - SP - CEP 17509-090 (adrimaroli@yahoo.com.br).

**Fonoaudióloga. Pós-Doutora em Ciências Médicas pela Faculdade de Ciências Médicas da Universidade Estadual de Campinas (FCM/Unicamp). Docente do Departamento de Fonoaudiologia e Programa de PósGraduação em Educação da FFC/Unesp.

***Trabalho Realizado no Departamento de Fonoaudiologia da FFC/Unesp - Marília - SP. Apoio: Fundação de Amparo à Pesquisa do Estado de São Paulo (Fapesp) Bolsa de Iniciação Científica.
\end{abstract}

Artigo Original de Pesquisa

Artigo Submetido a Avaliação por Pares

Conflito de Interesse: não

\begin{abstract}
Background: Brazilian adaptation of the reading processes assessment (Prolec). Aim: to characterize and compare the performance of students from public and private teaching institutions from the 1st to the 4th grades in the adaptation of the reading processes assessment (Prolec). Method: 262 students from the 1st to the 4th grades of elementary school participated in this study. Participants were distributed as follows: Group I (GI) consisted of 122 students from the 1st to the 4th grades of public elementary schools and Group II (GII) consisted of 140 students from the 1st to the 4th grades of private elementary schools. The adapted version of the reading processes assessment (Prolec) was applied. Results: the results indicated that GII performed better in tests of sound identification, word choosing, words reading, low-frequency words reading, pseudo-words reading, sentences comprehension and text comprehension. Both groups presented a lower performance than the expected in Prolec tests Spanish version. Conclusions: the adaptation of the Prolec to the Brazilian reality appears to be appropriate for the establishment of a reading profile of students, from public and private teaching institutions, who are undergoing the initial phase of literacy.
\end{abstract}

Key Words: Reading; Assessment; Learning.

\section{Resumo}

Tema: adaptação brasileira da avaliação dos processos de leitura (Prolec). Objetivo: caracterizar e comparar o desempenho de escolares do ensino básico público e privado de $1^{\mathrm{a}}$ a $4^{\mathrm{a}}$ séries na adaptação brasileira da avaliação dos Processos de Leitura (Prolec). Método: participaram deste estudo 262 escolares da $1^{\text {a à }} 4^{\text {a }}$ série do ensino básico, distribuídos em: Grupo I (GI), composto por 122 escolares de escola pública municipal e Grupo II (GII), composto por 140 escolares de escola particular. Como procedimento, aplicou-se a adaptação brasileira das provas de avaliação do Prolec. Resultados: os resultados revelaram que o GII apresentou desempenho superior em provas de identificação de som, decisão lexical, leitura de palavras, leitura de palavras de baixa frequência, leitura de pseudo-palavras, compreensão de orações e compreensão de textos. Tanto os escolares do GI como do GII apresentaram desempenho abaixo da pontuação esperada nas provas do PROLEC na versão espanhola. Conclusão: a adaptação do Prolec para a realidade brasileira mostrou-se adequada para o estabelecimento de perfil de leitura nos escolares de ensino público e particular em fase inicial de alfabetização.

Palavras-Chave: Leitura; Avaliação; Aprendizagem. 


\section{Introduction}

The recognition of a word in an alphabetical writing system can be explained by the dual route process, i.e., reading can occur through a process that involves phonological mediation (phonological route) or through the direct visual process (lexical route) 1-2.

Reading through the phonological route depends on the use of knowledge about the rules of conversion between grapheme and phoneme, in order to achieve the pronunciation of a word. So, a phonological code is created to be identified by the auditory recognition of words, triggering the meaning of the word. Reading through the lexical route depends on the previous knowledge of a word and on the memorization in the visual system of recognition of words and the recovering of their meaning and pronunciation through the direct lexical access, being the pronunciation fulfilled as a whole. Thus, words with different levels of alphabetical regularity can be read without problems 1-5.

In order to achieve competent reading there must be the quick and accurate recognition of the word. This quickness in the identification occurs due to the formation of the mental lexicon, when the familiar and high frequency words are visually recognized, while the new and low frequency word identification depends on phonological strategies, in which the reader makes association of the letters with their sounds6-10.

Yet, it is not possible to consider decoding as the only important factor in reading, the recognition and the comprehension must be considered as well. According to the literature11-13, the best way to evaluate the recognition of the words consists of the application of a real word reading, because in this way there are no psycholinguistic, pictorial and contextual suggestions, while in order to evaluate the decoding it is recommended the reading of nonwords since that determines the capacity of decoding unknown words. The comprehension can be evaluated by reading aloud.

Based on that, this study aims to characterize and to compare the performance of public and private elementary students, 1 st to 4 th grades, in the Brazilian adaptation of The Assessment of Reading Processes (PROLEC) 13.

\section{Method}

This study was approved by the Ethical Committee in Research of The Philosophy and Sciences Faculty of São Paulo State University - FFC/UNESP - Marília, under the protocol number 3240/2006.

Two hundred and sixty-two students from both genders participated in this study, the age of the group ranged from 7 years and 1 month to 10 years and 11 months old, attending 1st to 4th grades of municipal public schools, distributed into two groups:

. Group I(GI): Composed of 122 municipal public school students subdivided into GIa: 24 1st year graders, 37,5\% males and 62,5\% females; GIb: 33 2nd year graders, 51,5\% males and 48,5\% females; GIc: 33 3rd year graders, $45,2 \%$ males and $54,8 \%$ females and GId: 34 4th year graders, 47,1\% males and 52,9\% females. . Group II (GII): composed of 140 private school students subdivided into: GIIa: 37 1st year graders, 45,9\% males and 54,1\% females; GIIb: 34 2nd year graders, 58,8\% males and 41,2\% females; GIIc: 34 3rd year graders, 52,9\% males and 47,1\% females; GIId: 35 4th year graders, 51,4\% males and 48,6\% females.

After the signing of the Term of Free Consent, the students were submitted to the application of the Brazilian adaptation of The Assessment of Reading Processes (PROLEC) 13. This evaluation consists of four groups which were distributed to evaluate four reading processes, as follows:

-1st Process: consisting of two tests. The Test of Letters Identification whose aim is to verify the student's capacity of naming the letters and their representing sounds. The test of Same and Different in words and nonwords aims to verify the student's capacity in identifying, distinguishing and recognizing real words and invented ones as being same and different.

- 2nd Process: Lexical processes, consisting of four tests. In the Test of Lexical Decision, the student must recognize only real words in a list of real and invented ones. In tests of reading words, nonwords, and words and nonwords, the student must read real and invented words, being that on the first test the capacity of reading real words is measured, and on the second the capacity of reading invented words with different syllabic complexity is measured, divided in CCV, VC, CVC, CVV, CCVC, and CVVC. On the third test, the aim is to analyze the use of phonological and lexical route to reading. In order to do that, it was used words and nonwords which belonged to six categories: high frequency short words, high frequency long words, low frequency short words, low frequency long words, short nonwords and long nonwords.

- 3rd Process: Syntactical Processes, consisting of two tests. In the Grammar Structure test it is verified the student's capacity of choosing a period in different syntactical structures: active voice, passive voice and 
focused complement. In the Punctuation Marks Test, it was verified the student's capacity of using punctuation marks in a short text.

- 4th Process: Semantic Process, consisting of two tests: Clauses Comprehension and Text Comprehension. In these two tests, it was analyzed the student's capacity of understanding simple requests, phrases and texts.

The words and nonwords used in the Brazilian adaptation were extracted from lists which were distributed according to frequency, regularity and irregularity 14,15 , while the texts were extracted from textbooks of 1st to 4th grades that are used by the municipal school system of Marília-SP.

The evaluation was individually applied in two sessions of 40 minutes at the school, out of the class time.

The results of this study were analyzed statistically by the Mann-Whitney test, aiming to compare the student's performance according to their grades and type of school (public or private). We adopted the significance level of $5 \%(?=0.050)$ for the statistical test $\left(^{*}\right)$. In order to make the statistical analysis, the program used was the SPSS (Statistical Package for Social Sciences), version 13.0 .

\section{Results}

Table 1 presents the results of comparing GI and GII students. By analyzing it, statistical significant difference was verified in the identification of sounds and letters test, lexical decision test, words reading test, nonwords reading test, high and low frequency words reading test, punctuation marks test and text and clauses comprehension test, showing that GIIa students presented superior performance when compared to GIa, except in the same and different test.
Regarding the GIb and GIIb students, GIIb students presented superior performance when compared to GIb, except in the punctuation marks test. The results about the GIc and GIIc students showed a significant statistical difference in the identification of sounds and letters test, lexical decision test, words reading test, nonwords reading test, high and low frequency words reading test, punctuation marks test and text and clauses comprehension test, evidencing that GIIc students presented superior performance when compared to GIc, except in the same and different test.

Between the GId and GIId students there was a significant statistical difference in the tests of identification of sounds, of lexical decision, of words reading, of low frequency words reading, nonwords reading, text and clauses comprehension, showing that GIId students presented a superior performance when compared to GId.

Table 2 presents the results of comparing GI and GII students, by grade level, in the Grammar Structure Test. A significant statistical difference was identified among the groups, showing that the GIIa students presented superior performance in the identification of active and passive voice clauses, a low average of errors when compared to GIa at the same task. The GIIb students presented superior performance in the identification of passive voice clauses, as well as low average of errors when compared to GIb at the same task. The GIIc students presented similar performance in the identification of active and passive voice clauses and focused complement, as well as similar average of errors when compared to GIc at the same task. Finally, the GIId students presented superior performance in the identification of active voice clauses, as well as, a low average of errors when compared to GId at the same task. 
TABLE 1. Comparison of Performances of the GI and GII students, regarding the Prolec tests.

\begin{tabular}{|c|c|c|c|c|c|c|c|c|c|}
\hline Variable & Group & Mean & Standard Deviation & p - value & Variable & Group & Mean & Standard Deviation & p - value \\
\hline \multirow{8}{*}{ Sound } & GIa & 1,33 & 2,22 & \multirow{2}{*}{$0,000^{*}$} & \multirow{8}{*}{ Letter } & GIa & 19,25 & 0,90 & \multirow{2}{*}{$0,001 *$} \\
\hline & GIIa & 11,49 & 6,30 & & & GIIa & 19,86 & 0,35 & \\
\hline & GIb & 1,18 & 2,31 & \multirow{2}{*}{0,008} & & GIb & 18,94 & 2,54 & \multirow{2}{*}{$0,001 *$} \\
\hline & GIIb & 13,29 & 7,35 & & & GIIb & 19,97 & 0,17 & \\
\hline & GIc & 1,33 & 2,22 & \multirow{2}{*}{$0,000^{*}$} & & GIc & 19,25 & 0,90 & \multirow{2}{*}{$0,001 *$} \\
\hline & GIIc & 11,49 & 6,30 & & & GIIc & 19,86 & 0,35 & \\
\hline & GId & 1,29 & 3,29 & \multirow{2}{*}{$0,000^{*}$} & & GId & 19,94 & 0,24 & \multirow{2}{*}{0,148} \\
\hline & GIId & 16,60 & 4,97 & & & GIId & 20,00 & 0,00 & \\
\hline \multirow{8}{*}{ SD } & GIa & 19,00 & 1,25 & \multirow{2}{*}{0,161} & \multirow{8}{*}{ LD } & GIa & 27,08 & 3,06 & \multirow{2}{*}{$0,001 *$} \\
\hline & GIIa & 19,19 & 1,79 & & & GIIa & 29,05 & 1,93 & \\
\hline & GIb & 18,45 & 3,15 & \multirow{2}{*}{$0,000^{*}$} & & GIb & 27,15 & 2,69 & \multirow{2}{*}{$0,000^{*}$} \\
\hline & GIIb & 19,76 & 0,50 & & & GIIb & 29,00 & 1,76 & \\
\hline & GIc & 19,00 & 1,25 & \multirow{2}{*}{0,161} & & GIc & 27,08 & 3,06 & \multirow{2}{*}{$0,001^{*}$} \\
\hline & GIIc & 19,19 & 1,79 & & & GIIc & 29,05 & 1,93 & \\
\hline & GId & 19,38 & 1,48 & \multirow{2}{*}{0,603} & & GId & 28,06 & 1,72 & \multirow{2}{*}{$0,000 *$} \\
\hline & GIId & 19,23 & 1,48 & & & GIId & 29,63 & 0,65 & \\
\hline & GIa & 27,46 & 3,49 & $0003 *$ & & GIa & 17,21 & 2,62 & 0 006* \\
\hline & GIIa & 29,08 & 2,38 & 0,003 & & GIIa & 18,51 & 1,89 & \\
\hline & GIb & 27,88 & 4,59 & $0000 *$ & & GIb & 16,73 & 3,56 & $0000 *$ \\
\hline WR & GIIb & 29,76 & 0,65 & , & NWR & GIIb & 19,85 & 0,44 & 0,000 \\
\hline Wh & GIC & 27,46 & 3,49 & $0003 *$ & 10 & GIc & 17,21 & 2,62 & 0 006* \\
\hline & GIIc & 29,08 & 2,38 & & & GIIc & 18,51 & 1,89 & \\
\hline & GId & 29,26 & 1,05 & $0000 *$ & & GId & 18,76 & 1,48 & $0001 *$ \\
\hline & GIId & 29,94 & 0,34 & 0,000 & & GIId & 19,71 & 0,62 & \\
\hline & GIa & 18,54 & 2,36 & $0.000 *$ & & GIa & 17,79 & 1,84 & $0.001 *$ \\
\hline & GIIa & 19,92 & 0,36 & & & GIIa & 19,08 & 1,72 & \\
\hline & GIb & 18,97 & 2,66 & $0.000 *$ & & GIb & 17,64 & 3,07 & $0.000 *$ \\
\hline WR HF & GIIb & 20,00 & 0,00 & & WR LF & GIIb & 19,88 & 0,41 & \\
\hline & GIC & 18,54 & 2,36 & $0.000 *$ & & GIc & 17,79 & 1,84 & $0.001 *$ \\
\hline & GIIc & 19,92 & 0,36 & & & GIIc & 19,08 & 1,72 & \\
\hline & GId & 19,82 & 0,63 & 0279 & & GId & 18,88 & 1,41 & $0009 *$ \\
\hline & GIId & 19,97 & 0,17 & 0,270 & & GIId & 19,63 & 0,81 & \\
\hline & GIa & 17,21 & 2,62 & $0006 *$ & & GIa & 1,75 & 1,51 & $0000 *$ \\
\hline & GIIa & 18,51 & 1,89 & 0,000 & & GIIa & 4,16 & 2,44 & \\
\hline & GIb & 16,73 & 3,56 & $0000 *$ & & GIb & 3,79 & 2,20 & 0172 \\
\hline NWR & GIIb & 19,85 & 0,44 & 0,000 & PM & GIIb & 4,50 & 2,09 & $0,1 / 2$ \\
\hline & GIC & 17,21 & 2,62 & $0.006 *$ & Fiv & GIc & 1,75 & 1,51 & $0.000 *$ \\
\hline & GIIc & 18,51 & 1,89 & 0,000 & & GIIc & 4,16 & 2,44 & \\
\hline & GId & 18,76 & 1,48 & $0.001 *$ & & GId & 6,82 & 2,05 & 0.904 \\
\hline & GIId & 19,71 & 0,62 & 0,001 & & GIId & 6,86 & 2,98 & \\
\hline & GIa & 10,29 & 1,92 & $0001 *$ & & GIa & 8,63 & 3,24 & $0000 *$ \\
\hline & GIIa & 11,65 & 0,54 & , & & GIIa & 12,08 & 4,13 & 0,000 \\
\hline & GIb & 10,64 & 1,78 & $0000 *$ & & GIb & 9,97 & 4,34 & $0.000 *$ \\
\hline CS & GIIb & 11,82 & 0,46 & 0,000 & TC & GIIb & 14,74 & 1,11 & \\
\hline C & GIC & 10,29 & 1,92 & $0,001 *$ & & GIC & 8,63 & 3,24 & $0,000 *$ \\
\hline & GIIc & 11,65 & 0,54 & & & GIIc & 12,08 & 4,13 & \\
\hline & GId & 11,74 & 0,51 & $0,035^{*}$ & & GId & 13,41 & 1,83 & $0,000 *$ \\
\hline & GIId & 11,94 & 0,24 & & & GIId & 15,00 & 1,14 & \\
\hline
\end{tabular}

Caption: SD: Same and Different, LD: Lexical Decision; WR: Word reading, WR HF: High Frequency Words Reading, WR LF: Low Frequency Words Reading, NWR: nonwords Reading, PM: Punctuation Marks, CC: Clauses Comprehension, TC: Texts Comprehension. 
TABLE 2. Comparison of the students from private and public school, by grade level, regarding their performances in the Grammar Structure Test.

\begin{tabular}{|c|c|c|c|c|c|c|c|c|c|}
\hline able & Group & Mean & Standard Deviation & p - value & Variable & Group & Mean & Standard Deviation & p - value \\
\hline \multirow{8}{*}{ V } & GIa & 5,00 & 1,35 & \multirow{2}{*}{$0,024 *$} & \multirow{8}{*}{ FC } & GIa & 2,13 & 0,90 & \multirow{2}{*}{0,784} \\
\hline & GIIa & 5,89 & 1,29 & & & GIIa & 2,19 & 1,00 & \\
\hline & GIb & 5,79 & 1,47 & \multirow{2}{*}{0,181} & & GIb & 2,48 & 1,20 & \multirow{2}{*}{0,712} \\
\hline & GIIb & 6,32 & 1,09 & & & GIIb & 2,24 & 0,78 & \\
\hline & GIc & 5,87 & 1,43 & \multirow{2}{*}{0,051} & & GIC & 2,16 & 0,69 & \multirow{2}{*}{0,503} \\
\hline & GIIc & 6,47 & 1,38 & & & GIIc & 2,03 & 1,00 & \\
\hline & GId & 5,47 & 1,21 & \multirow{2}{*}{$0,000^{*}$} & & GId & 2,62 & 1,10 & \multirow{2}{*}{0,474} \\
\hline & GIId & 6,60 & 0,85 & & & GIId & 2,43 & 0,81 & \\
\hline \multirow{8}{*}{ V } & GIa & 3,79 & 1,50 & \multirow{2}{*}{$0,005^{*}$} & \multirow{8}{*}{ Errors } & GIa & 5,04 & 2,46 & \multirow{2}{*}{$0,001 *$} \\
\hline & GIIa & 4,92 & 1,53 & & & GIIa & 3,00 & 1,90 & \\
\hline & GIb & 5,00 & 1,62 & \multirow{2}{*}{$0,013^{*}$} & & GIb & 2,91 & 2,84 & \multirow{2}{*}{$0,012 *$} \\
\hline & GIIb & 5,97 & 1,17 & & & GIIb & 1,47 & 1,71 & \\
\hline & GIC & 6,13 & 1,38 & \multirow{2}{*}{0,378} & & GIc & 1,81 & 1,17 & \multirow{2}{*}{0,118} \\
\hline & GIIc & 5,79 & 1,27 & & & GIIc & 1,71 & 2,32 & \\
\hline & GId & 6,06 & 1,32 & \multirow{2}{*}{0,326} & & GId & 1,82 & 1,49 & \multirow{2}{*}{$0,000 *$} \\
\hline & GIId & 6,37 & 1,24 & & & GIId & 0,63 & 1,06 & \\
\hline
\end{tabular}

Caption: AV: Active Voice, PV: Passive Voice, FC: Focu sed Complement.

\section{Discussion}

In the Brazilian adaptation, the GII students presented a superior performance compared to GI, but both groups presented performances below the expected score in the tests of identification of letters and graphemes, same and different, lexical decision, reading words and nonwords, punctuation marks, grammar structure and comprehension of clauses and texts. In the Spanish adaptation 16 , there was no difference in the reading profile of the students from public and private schools.

The GII students presented superior performance compared to the GI in the test identification of letters and graphemes, which can be explained by the absence of teaching the correspondence between letters and sounds in class at the public schools3,7,17-19.

In a system of alphabetic based writing, the ability of decoding is very important in the beginning of the reading process, because it provides the basis for the automaticity in recognizing the word and later the comprehension of the reading material 3-4,9,20-21.

In the lexical decision test, the GII students had a superior performance compared to the GI students, that is, they recognized the real words more easily. In the same and different test with words and nonwords, the performance of GI and GII was similar, being that most of the errors were on words and nonwords that contain the simple grapheme (CV) and the complex grapheme (CCV) contraposition.

In the test of reading words and nonwords, the average of the GI and GII students was improved according to the increase of the grade level, however, when the performances were compared by schools, the best performances were from the GII in reading words and nonwords compared to GI.

The difference between the averages of reading nonwords from first to fourth grades, regardless of the type of school, revealed that among the first graders the use of phonological route is superior in relation to the fourth graders, showing that in the beginning of the alphabetization the use of the phonological route overlays the lexical route, while at the fourth grade, due to the knowledge of orthography, the lexical route is more used, according to the literature3,9,12,20,22-23.

In the grammar structures test, the GIa, GIIa, GIb and GIIb students frequently succeeded in active voice clauses while the GIc, GIIc, GId and 
GIId students succeeded in active and passive voice. The index of errors was considerably low, but the performance of GII was superior in correct answers compared to GI.

In the test of punctuation marks, comprehension of clauses and texts, the GII had a superior performance when compared to GI. However, we highlight that between the GId and the GIId the difference was not observed in the test of punctuation marks.

The superior performance of GII may have occurred due to a better use of the lexical route during reading, because, phonological and orthographical skills correlate with each other by the processing of a sentence during reading, as they interfere directly with the grammar and semantic structure of a word in a sentence and in a text24.

\section{References}

1. Pinheiro AMV, Lúcio PS, Silva DR. Avaliação cognitiva de leitura: o efeito de regularidade grafema-fonema e fonemagrafema na leitura em voz alta de palavras isoladas no português do Brasil. Psicol Teor Prat. 2008;10(2):16-30.

2. Cunha VLO, Capellini SA. Leitura: decodificação ou obtenção do sentido?. Rev Teias. 2009;10 (19):1-21.

3. Cunha VLO, Capellini SA. Análise psicolinguística e cognitivo-linguistica das provas de habilidades metalinguísticas e leitura realizadas em escolares de $2^{\mathrm{a}}$ a $5^{\mathrm{a}}$ série. Rev. Cefac [periódico na internet]. Epub 23-abr-2010 [acesso em 2010 set 20]: 10p. Disponível: http:// www.scielo.br/scielo.php?script=sci_arttext\&pid=S1516$18462010005000017 \& \operatorname{lng}=$ pt $\&$ nrm $=$ isso

4. Germano GD, Pinheiro FH, Cunha VLO. Avaliação e intervenção nas habilidades metalinguísticas In: Capellini SA, Germano GD, Cunha VLO,editores. Transtornos de aprendizagem e transtornos da atenção: da avaliação à intervenção. São José dos Campos, SP: Pulso Editorial. 2010. p. $35-48$

5. Pinheiro FH, Capellini SA. Treinamento auditivo em escolares com distúrbio de aprendizagem. Pró-Fono Revista de Atualização Científica. 2010;22(1):49-54.

6. Paula GR, Mota HB, Keske-Soares MA. A terapia em consciência fonológica no processo de alfabetização. PróFono: Ver Atual Cient. 2005;17(2):175-84.

7. Mcquiston K, O'Shea D, MCcollin M. Improving phonological awareness and decoding skills of high schools students from diverse backgrounds. Prev Sch Failure. 2008;52(2):67-70.

8. Smythe I, Everatt E, Al-Menaye NHX, Capellini S, Gyarmathy E, Siegel L. Predictors of word-level literacy amongst grade 3 children in five diverse languages. Dyslexia. 2008;14(3):170-87.

\section{Conclusion}

It's possible to conclude by the results of this study that the GII students presented a superior performance in tests of sound identification, lexical decision, word reading, low frequency word reading, nonword reading, punctuation marks, clauses comprehension compared to the GI students, showing that the ones who attend private schools, compared to the ones that attend public schools, present better comprehension of the alphabetic principle of Portuguese, which provides a basis for a better automaticity in recognizing a word and consequently the comprehension of texts.

Thus, it can be considered that the adaptation of PROLEC to the Brazilian reality was sensitive and appropriate to establish the reading profile of the public and private school students in the beginning of literacy. So, it is expected that this procedure becomes an instrument used in the evaluation of reading processes by professionals and students of the speech language therapy area.

9. Leppänen U, Kaisa A, Pekka N, Jari-Erik N. Letter knowledge predicts grade 4 reading fluency and reading comprehension. Learn Instr. 2008;18:548-64.

10. Roman AA, Kirby JR, Parrila RK, Wade-Woolley L, Deacon SH. Toward a comprehensive view of the skills involved in word reading in grades 4, 6, and 8. J Exp Child Psychol. 2009;102(1):96-113.

11. Nikolopoulos D, Goulandris N, Hulme C, Snowling MJ. The cognitive bases of learning to read and spell in Greek: evidence from a longitudinal study. J Exp Child Psychol. 2006;94(1):1-17.

12. Nation K, Cocksey J. The relationship between knowing a word and reading it aloud in children's word reading development. J Exp Child Psychol. 2009;103(3):296-308.

13. Capellini SA, Oliveira AM, Cuetos F. PROLEC; provas de avaliação dos processos de leitura. São Paulo (SP): Casa do Psicólogo; 2010.

14. Pinheiro AMV. Leitura e escrita: uma abordagem cognitiva. Campinas: Psy II; 1994.

15. Pinheiro, AMV. Avaliação cognitiva das capacidades de leitura e de escrita de crianças nas séries iniciais do Ensino Fundamental - AVACLE. Relatório Final Global e Integrado de atividades desenvolvidas, submetido ao Conselho Nacional de desenvolvimento cientifico e tecnológico (CNPq); 2003.

16. Cuetos F, Rodríguez B, Ruano E. Evaluación de los procesos lectores. Madrid: TEA Ediciones; 1996.

17. Salgado CA, Capellini SA. Programa de remediação fonológica em escolares com dislexia do desenvolvimento. Pró-Fono Revista de Atualização Científica. 2008; 20(1):31-6.

18. Germano GD, Pinheiro FH, Capellini SA. Desempenho 